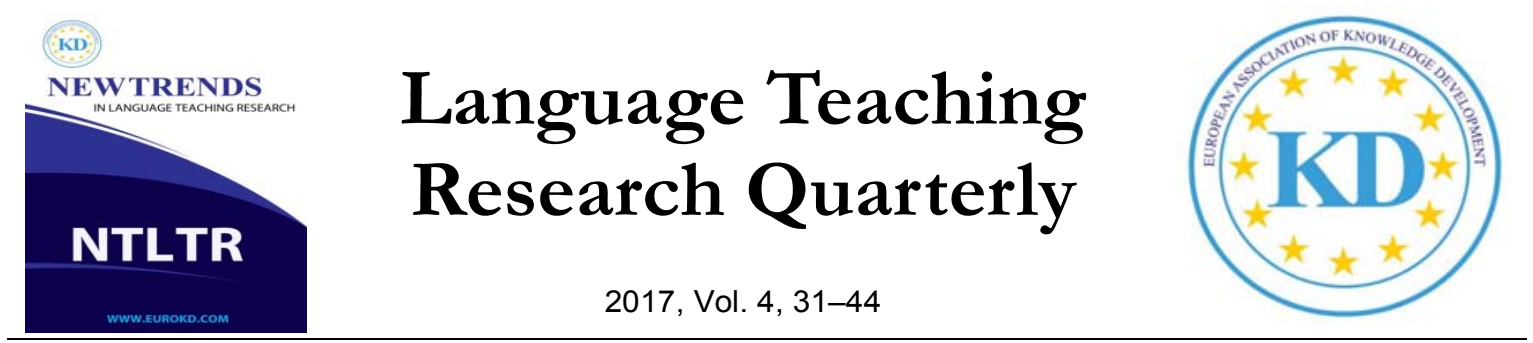

\title{
Listening Skills Development in the Context of Learner-Oriented Approach
}

\author{
Liudmila A. Egorova \\ Peoples' Friendship University of Russia, Russian Federation, Russia
}

Received 17 August 2017 Accepted 22 December 2017

\begin{abstract}
The article considers the issues connected with the second language (L2) learning and listening comprehension, in particular. The role of various characteristics of learners' personality in the L2 acquisition is discussed. The results of experimental study including 35 Russian-speaking learners of English showed that the level of trait anxiety influences the process of mastering the L2 listening skills. Learners with high trait anxiety levels show low speed of the processes of logical thinking as well as rapid learning fatigue. Individuals with low trait anxiety are characterized by a relatively slow learning progress despite the stability of the results. The analysis of learning strategies including metacognitive, cognitive, memory-related, compensatory, social and affective ones allowed us to single out those compensatory strategies which mitigate the negative impact of certain psychological peculiarities.
\end{abstract}

Keywords: L2 Skills Acquisition, Listening Comprehension, Compensatory Learning Strategies, Trait Anxiety.

\section{Introduction}

Studying the information processing in terms of a foreign language acquisition is becoming increasingly important nowadays. The results in this field may be beneficial both for theoretical and applied linguistics, especially for teaching foreign languages methodology. Modern approaches to the intensification of foreign languages studying require the development of new methods of teaching the skills of foreign speech perception and comprehension, listening for gist and details, using the information in other activities. All that is impossible without the analysis of listening comprehension processes in the context of the situation of communication. The 
characteristics of the participants are bound to play the crucial role for the successful communication.

The article aims at analyzing the specific characteristics of speech communication in learning environments, and the study of the semantic perception of sounding mini-texts by Russianspeaking students with different personal typology (level of trait anxiety). As a result, some principles for changing the educational process and selecting the audio material are to be proposed.

\section{Learners' Personality and Listening Comprehension in the Conditions of Task- Based Language Teaching}

The notion of task-based language teaching (TBLT) has been introduced to denote the approach considering the tasks in the classroom as tools helping the students to use the language for nonlinguistic activities focusing mainly on meaning exchange (Long, 1985, Prabhu, 1987). So different ways were investigated to help students find themselves in activities revealing the goals of interlanguage communication and focus on the functional tasks rather than mechanical drills (Littlewood, 2000).

Thus, the methods of teaching are to be adopted not only to the current needs of the learners but to their individual characteristics, which are of primary interest for many researchers (Bradley \& Hebert, 1997; Ehrman \& Oxford, 1995; Ehrman, 1993; Hjelle and Ziegler, 1992; Nasrabadi, 1996; Behdokht Mall-Amiri \& Nazanin Nakhaie, 2013; Feist \& Feist,. 2006; Kolb. \& Kolb, 2005; Markham, 2004). Learning style peculiarities influencing the information processing led to the classification of learning styles depending on levels of learning processes. The outer layer comprises instructional preferences, the middle layer is called the information processing style, the inner layer is termed as cognitive personality style (Curry, 1983).

As far as factors affecting listening comprehension is concerned, Anderson and Lynch (1988) singled out the following:

- Personal Style

- Intelligence

- Attitude

- Gender

- Culture

- Message and Speaker

- Personal Traits

These factors determine the learners' selectivity, anticipation, credibility, attention, comprehension and retention.

Among personal traits Tucker, Hamayan and Genesee (1976), Nasrabadi (1996), Daneshvari (1996), Brown (1994), Mall-Amiri and Nakhaie (2013) paid special attention to extraversionintroversion, though the results of experimental studies are sometimes contradictory. For 
example, Nasrabadi (1996) and Daneshvari (1996) found significant results for extroverts and came to the conclusion that introverts were worse listening strategy users in comparison with extroverts. However, Mall-Amiri and Nakhaie (2013) proved that introverts were better at listening than extraverts.

Another essential factor influencing successful performance in the classroom communication is the level of state anxiety. Saito and Samimy (1996), Kitano (2001) and Ewald (2007) concluded that elementary or intermediate level students experienced lower anxiety than advanced students. Aydemir (2011) showed that university students demonstrated increased foreign language anxiety levels at the end of the academic year. However, some studies (Chapelle \& Roberts, 1986) proved that it decreases when proficiency and experience develop.

Anxiety in listening situations may be caused by the fear of the speaker's misinterpreting or misunderstanding, the type and structural peculiarities of the message, the level of motivation the listener experiences. Serraj (2015) identified three types of factors influencing the listening anxiety and divided them into the following categories: individual, environmental and input ones. "The individual factors include factors that refer to the individuals' characteristics and situation of learners and include nerves and emotionality, inappropriate strategies and lack of practice. The environmental factors ... include factors that exist in the classroom atmosphere and influence the learners' level of listening anxiety. These include instructors, peers and class environment. Input factors refer to characteristic of listening input including lack of time to process, lack of visual support, nature of speech and level of difficulty" (Serraj, 2015, p.6). The research proved that "a higher level of listening anxiety is observed among language learners, students tend to have lower performance in listening tasks" (Serraj, 2015, p.6).

Trait anxiety also plays a significant role in learners' performance. It usually understood as "the stable tendency to attend to, experience, and report negative emotions such as fears, worries, and anxiety across many situations. This is part of the personality dimension of neuroticism versus emotional stability. Trait anxiety also manifests by repeated concerns about and reporting of body symptoms. Trait anxiety is characterized by a stable perception of environmental stimuli (events, others' statements) as threatening. Trait-anxious people often experience and express also state anxiety, in situations in which most people do not experience such responses." (Encyclopedia of Behavioral Medicine, 2013, p.1989). Negative correlation between the level of trait anxiety and academic performance is usually noticed (Cassady \& Johnson, 2002; Koch \&Terrell, 1991; Liu, 2006; MacIntyre \&Gardner, 1994; MacIntyre, 1999).

Thus, listening comprehension and understanding in a broader sense in the conditions of taskbased language teaching (TBLT) are directly related to listening as a kind of speech activity included in higher-level activity connected with the learning process. Therefore, we may point out the following specific characteristics of the communication situation, closely related to the variability of the characteristics of the sounding speech and the general state of the speaker and listener, and consequently, with the successful listening comprehension:

Specific (educational) goals of speech communication and, consequently, limited, predictable subject of speech utterances. Selection of the speech material used by the teacher; 
1. The possibility of changing tasks in the process of communication by the teacher;

2. Relatively constant conditions in which the act of speech proceeds, the environment of the speakers, the place of the communicative act (the classroom, the language laboratory);

3. Using a non-native language;

4. Relatively short-term speech act;

5. Usually the absence of any non-verbal actions of students when speaking;

6.Absence of a common apperception base for communicants. Different awareness of the subject of speech among students, the teacher and students;

7.Constant evaluation of speech performance, including corrections of the surface structure of the utterance by the teacher;

8. The reactive role of students in communication;

9.The complex structure of social roles (especially in role-playing games, which are the basis of modern intensive methods of teaching foreign languages) and, as a result, the emotional tension of students and teachers.

Further analysis of the problem in question led to the conclusion that it is necessary to carry out a set of experiments aimed at identifying factors that determine the course of cognitive processes associated with the processing of verbal information; as well as the development of certain experimental techniques that allow us to identify the relationship between the nature of the semantic perception of foreign-sounding material and the individual characteristics of the communicant.

\section{Materials and Methods}

The respondents were 35 Russian students ( 25 female, 10 male), aged 18-22, of the Peoples' Friendship University of Russia (Engineering faculty). The level of English was defined as B1 (18 respondents) and B2 (17 respondents) on the basis of multiple testing (standard Cambridge FCE and PET tests) and the teacher's assessment (a special questionnaire was compiled to help the teacher evaluate the students' skills development). According to A Common European Framework of Reference for Languages: Learning, Teaching, Assessment (2001), a B1 student can "generally follow the main points of extended discussion around him/her, provided speech is clearly articulated in standard dialect; give or seek personal views and opinions in an informal discussion with friends; express the main point he/she wants to make comprehensibly; exploit a wide range of simple language flexibly to express much of what he or she wants to; maintain a conversation or discussion but may sometimes be difficult to follow when trying to say exactly what he/she would like to; keep going comprehensibly, even though pausing for grammatical and lexical planning and repair is very evident, especially in longer stretches of free production"(CEFRL, p.34) whereas a B2 student can "account for and sustain his opinions in discussion by providing relevant explanations, arguments and comments; explain a viewpoint on a topical issue giving the advantages and disadvantages of various options; construct a chain of reasoned argument; develop an argument giving reasons in support of or against a particular point of view; explain a problem and make it clear that his/her counterpart in a negotiation must 
make a concession; speculate about causes, consequences, hypothetical situations; take an active part in informal discussion in familiar contexts, commenting, putting point of view clearly, evaluating alternative proposals and making and responding to hypotheses" (CEFRL, p.35).

The level of anxiety was measured on the basis of the State-Trait Anxiety Inventory (STAI) by Charles Spielberg adopted by Yu. Khanin (Khanin 1976) and the Taylor Manifest Anxiety Scale (by Janet Taylor) adopted by V. Norakidze (Norakidze 1989). 16 student showed high level of trait anxiety, 19 - moderate or low levels of trait anxiety.

The experimental study consisted of text perception, text comprehension and text extension experiments. Speech fragments were presented orally and in writing, with the type of the corresponding written text being varied. The type of operations of the respondents with them also changed, namely, perception, comprehension, reproduction, comparison, paraphrasing, continuation.

\section{Text perception}

Stage 1. The respondents were to reproduce in writing semantic and grammatical structure of the phrase after listening to it once. The first series consisted of 37 sentences, the second -49.

Stage 2. Respondents were shown a dialogue consisting of two replies in writing. The task was to listen to a similar dialogue and point out the differences in the written text.

The written dialogues included the following differences (see example in Table 1):

1) addition of a new speech patterns, not changing the overall meaning of the reply;

2) the replacement of a speech patterns by a synonymous one;

3) omission of the word-combination, which is an adverbial modifier or an object, not altering the overall meaning of the reply;

4) omission of the word-combination, which is an adverbial modifier or an object, changing the overall meaning of the reply;

5) addition of new words in a group of homogeneous objects;

6 ) addition of the words, not altering the overall meaning of the phrase;

7) addition of the words altering the overall meaning of the phrase;

8) use of different grammatical forms of words, synonymous in this context;

9) replacement of the words by nonsynonymous ones;

10) changes to figures or proper names;

11) omission of a word without altering the overall meaning of the phrase;

12) omission of a word, altering the overall meaning of the phrase. 
Table 1. Examples of differences between written and oral versions of dialogues excerpts.

\begin{tabular}{l|l|l}
\hline No & $\begin{array}{l}\text { Dialogue excerpt presented to the } \\
\text { respondents in writing }\end{array}$ & $\begin{array}{l}\text { Corresponding uttered dialogue excerpt presented to } \\
\text { the respondents }\end{array}$ \\
\hline 1 & could you tell me what is in... & what is in... \\
\hline 2 & I know what to do! & I've got an idea! \\
\hline 3 & What is in this big bag? & what is in this big bag over there \\
\hline 4 & $\begin{array}{l}\text { there won't be enough time to have } \\
\text { dinner }\end{array}$ & there won't be enough time to go home for dinner \\
\hline 5 & $\begin{array}{l}\text { I bought some fruit: apples, peaches, } \\
\text { oranges, pears, bananas and grapes }\end{array}$ & I bought some apples, peaches, pears and grapes \\
\hline
\end{tabular}

\begin{tabular}{l|l|l}
\hline 6 & $\begin{array}{l}\text { did your parents like the play that they } \\
\text { attended last week }\end{array}$ & did your parents like the play they attended last week \\
\hline 7 & I could not miss it & I could miss it \\
\hline 8 & When does the ballet begin? & when does the ballet start? \\
\hline 9 & They saw it last month & they saw it last week \\
\hline 10 & it starts at six & it starts at seven \\
\hline 12 & There won't be_time... & There won't be enough time... \\
\hline
\end{tabular}

\section{Text comprehension}

This experiment was conducted right after the experiment on the accuracy of the dialogues perception. In addition, the respondents were to evaluate 3 control written phrases for each dialogue as true or false. The control phrase was considered true if it could serve as a semantic consequence of one of the statements contained in the dialogue, not coming into conflict with any other, or it followed from the conditions of the success of the speech act and the principle of communicative cooperation.

\section{Text extension}

The respondents were asked after a single listening to the dialogue (British English) consisting of two replies, to write it down and make up the continuation of it (as many replies as possible within 3 minutes). The number of dialogues is 10 . The examples of the texts produced by respondents are reproduced in Table 2 .

\section{Results}

The conditions of carrying out the experiment for the reproduction and continuation of the dialogues ensured that the listeners concentrate not on reproducing the dialogue they heard, but on writing its continuation within a limited period of time, which led to control reduction in writing, parallelism in the processes of internal programming and speech production. The 
intensity of the work of the respondents, the lack of written support allows us to trace the transformation of the surface structure of the dialogue into its deep understanding, to identify the main factors that influence this process.

Table 2. Examples of linguistic material received from the respondents classified according to the type of operations they performed.

\begin{tabular}{|c|c|c|c|}
\hline Oral text excerpt & $\begin{array}{l}\text { Corresponding written } \\
\text { text excerpt }\end{array}$ & $\begin{array}{l}\text { Operation performed by } \\
\text { respondents with the } \\
\text { text }\end{array}$ & $\begin{array}{l}\text { Text produced by } \\
\text { respondents }\end{array}$ \\
\hline $\begin{array}{l}\text { a businessman } \mid \text { is } \\
\text { talking to a group of } \\
\text { students } \|\end{array}$ & - & Written reproduction & $\begin{array}{l}\text { "The businessman is talking } \\
\text { two groups..". }\end{array}$ \\
\hline $\begin{array}{l}\text { I'm afraid|I have not } \\
\text { quite finished\| }\end{array}$ & - & Written reproduction & $\begin{array}{l}\text { "I'm afraid I haven't quiet } \\
\text { finish." }\end{array}$ \\
\hline $\begin{array}{l}\text { Nancy | why were you } \\
\text { late for the class } \\
\text { | this morning } \mid \\
\text { I overslept | and } \\
\text { missed the bus } \|\end{array}$ & $\begin{array}{l}\text { Nancy, I wonder, why } \\
\text { you were not in time } \\
\text { for the work that } \\
\text { morning. } \\
\text { I overslept and that's } \\
\text { why missed the train. }\end{array}$ & $\begin{array}{l}\text { Written version of the } \\
\text { dialogue correction in } \\
\text { accordance with the oral } \\
\text { one }\end{array}$ & $\begin{array}{l}\text { "Nancy, (I wonder), why did } \\
\text { you miss your class you were } \\
\text { not in time for the work that } \\
\text { morning. } \\
\text { - I overslept and (that's why) } \\
\text { missed the train bus." }\end{array}$ \\
\hline $\begin{array}{l}\text { - has George } \\
\text { returned from }\end{array}$ & $\begin{array}{l}\text { - Did George return } \\
\text { from Europe yet? }\end{array}$ & $\begin{array}{l}\text { Written version of } \\
\text { the dialogue }\end{array}$ & $\begin{array}{l}\text { - Did George return from } \\
\text { Europe yet? }\end{array}$ \\
\hline $\begin{array}{l}\text { Europe yet } \| \\
\text { - yes | but he was only } \\
\text { here for three days | } \\
\text { before his company } \\
\text { sent him to Canada\| }\end{array}$ & $\begin{array}{l}\text { - Yes, but he spent here } \\
\text { only } 4 \text { days before he } \\
\text { was sent to Canada. } \\
\text { 1. George has never } \\
\text { been to Europe. } \\
\text { 2. George was here } \\
\text { only } 4 \text { days. } \\
\text { 3. The company wants } \\
\text { to send George to } \\
\text { Canada. }\end{array}$ & $\begin{array}{l}\text { correction in } \\
\text { accordance with the } \\
\text { oral one. True/False } \\
\text { phrases assessment. }\end{array}$ & $\begin{array}{l}\text { - Yes, but he spent here only } 4 \\
\text { days before he was sent to } \\
\text { Canada." } \\
\text { 1. false } \\
\text { 2. true } \\
\text { 3. true }\end{array}$ \\
\hline $\begin{array}{l}\text { - did you enjoy the } \\
\text { concert | on } \\
\text { Saturday } \| \\
\text { - yes and no \| it was } \\
\text { very noisy and } \\
\text { crowded | and I didn't } \\
\text { enjoy that | but it was } \\
\text { exciting } \|\end{array}$ & - & $\begin{array}{l}\text { Written } \\
\text { reproduction and } \\
\text { continuation }\end{array}$ & $\begin{array}{l}\text { "- Did you enjoy the } \\
\text { concert on Saturday? } \\
\text { - Yes and no. It was noisy } \\
\text { and crowded. But it was } \\
\text { exciting too. } \\
\text { - But I liked it. I usually get a } \\
\text { good pleasure by meeting } \\
\text { new people and speaking } \\
\text { with them. That's why I } \\
\text { enjoyed the Saturday } \\
\text { concert very much." }\end{array}$ \\
\hline
\end{tabular}


The communicative actions that are usually expressed with the help of speech clichés, greetings, gratitude, congratulations, permission to enter, were well recognized (more than $70 \%$ of the respondents). In dialogues of an informative type (interview), the speech material expressing the information request was well reproduced, the structure of the response part was transmitted in a simplified form, with a large amount of the replies (more than 3 phrases), the respondents completely or partially lacked the information contained in the non-original phrase of the reply. In addition to losses in the reproduction of relatively large information blocks, all respondents (more than $80 \%$ ) are characterized by poor reproduction of the phatic elements, unstressed in the material used; greetings and appeals in the second reply of the dialogue. Apparently, this is due to the low information significance of these elements, serving, first of all, to maintain contact between the interlocutors.

Thus, with the intensification of work, the concentration of attention not on reproduction but on the continuation of the dialogue, the lack of written support, the process of the semantic perception of the dialogue changes: the perceptual units are enlarged, these units are graded in importance for communication, and the evaluation of the units under consideration is affected by the degree of expression of their constituent elements; The processing of the surface structure of the constituent units of dialogue (replies, phrases, syntagmas) occurs with the involvement of long-term memory mechanisms, so that when the dialogues are reproduced, the respondents again generate the dialogue they heard, focusing on certain semantic bearings expressing the communicative orientation of the dialogue elements. This explains the large number of paraphrases and the relatively accurate reproduction of speech clichés.

So all respondents at this stage of training are characterized by:

1) the dependence of the element perception o on the degree of its expression due to its role in the semantico-syntactic structure of the phrase;

2) when comparing a written text with a sounding speech, the listener's attention is primarily focused on the written text;

3) the relationship between the graphic and phonetic form of the word is formed in the listener, which causes the concentration of attention primarily on those elements whose form significantly differs from the existing record of the corresponding fragment;

4) the semantic perception of sounding and writing texts (in this case, each dialogue can be considered as such) involves rather large fragments, and only when evaluating the corresponding fragments as "different in meaning" the attention of the listener concentrates on smaller elements (usually carrying an essential semantic load).

The results of comparing experimental data obtained from "high-achieving respondents" and "low-achieving respondent" (that this division is rather arbitrary and reflects the results of an expert evaluation of the communicative competence of respondents by the leading teacher by the method of included observation) were interesting in terms of tracing different strategies used by the respondents.

Thus, for high-achieving respondents a relatively accurate reproduction of a series of isolated phrases with a low number of common errors is typical. The correctness of reproduction 
is due to the speed of phrases pronouncing, the phonetic quality of segments, the place of the reproduced element in the phrase, the syntagma. The respondents, despite the developed skills of speaking and writing, lacked the ability to adapt to a faster pace of speech, change the phonetic appearance of words, automatically perceive conversational formulas, which led to a slowing down of the processes of semantic perception of speech.

In comparison with the high-achieving respondents, the low-achieving respondents are characterized by a greater number of errors of all types, with about $30 \%$ of them occurring in the majority of answers by the respondents in this group. There are twice as many spelling errors that are massive in nature, unlike high-achieving respondents, where such errors were individual. There were difficulties with the analysis of the morphological structure of the word and, as a consequence, with the identification of the syntactic role of the word in the sentence. Just as for high-achieving respondents, however, for the most part, the low-achieving respondents are characterized by difficulties in the reproduction of initial unstressed and weakly expressed words, the absence of an internal correction of the grammatical correctness of the reproduced phrases when the phonetic appearance of the segments changes.

Low-achieving respondents did not comprehend and reproduce complex syntactic models, in particular, passive construction, lexical units that are not in active use, syncategorematic unstressed and weakly expressed words. In addition, a significant role is played by problems associated with an insufficient volume of active vocabulary and automatic grammar skills, which leads to a significant slowdown in the processes of semantic perception. As a result, phrases pronounced at a moderate pace (SDS $=188-200 \mathrm{~ms}$ ) are difficult to reproduce. Of great importance is the overall duration of the phrase. Gaps and replacements occurred more than in $50 \%$ of respondents with a phrase length exceeding $1.2 \mathrm{~s}$. It especially concerned the phrases consisting of one syntagma.

Unlike high-achieving respondents, where the skipping and replacement of a part of the phrase usually did not lead to the non-reproduction of the rest of the phrase, the low- achieving respondents' misunderstanding of the phrase element caused the omission of other elements of the phrase or the refusal to reproduce it at all.

When analyzing the results of the experiment to determine the accuracy of the dialogues perception, it is evident that on average the high-achieving respondents give more correct answers. Especially high differences ( 2 - 4 times) between high-achieving respondents and lowachieving respondents can be noticed at perception of:

- omission of the middle-word,

- omission of an expression giving additional information,

- substituting expressions for synonymous,

- substituting a word for phonetically similar as synonymous, and not,

- insertion of a word that does not change the general meaning of a phrase, usually a mediumsized phrase. 
This is explained by the automation of the processing of incoming information. For the low-achieving respondents, it is sufficient for a semantic perception of the basic idea of the dialogue, i.e. those of its elements that are very salient, for high-achieving respondents - for processing medium-sized elements that transmit additional information or perform a linking function.

The study highlighted different strategies of text perception by high-achieving and lowachieving respondents:

- high-achieving respondents are oriented at larger text fragments - phrases,

replies;

- low-achieving respondents are characterized by slower information processing, which leads to worse results with longer dialogues and more complicated tasks; they are concentrated on accentuated elements and miss the following unstressed elements.

Moreover, the level of trait anxiety affects the success of the semantic perception of foreign speech. The respondents with moderate or low levels of traits anxiety focus mainly on the written text, which leads to worse results for lengthy dialogues or dialogues with many differences between written and uttered versions (see examples in Table 3).

Table 3. Examples of identifying the difference in the omission of a word without changing the overall meaning of the phrase by respondents with different levels of trait anxiety.

\begin{tabular}{|c|c|c|c|c|c|}
\hline \multirow{3}{*}{$\begin{array}{l}\text { Uttered dialogue } \\
\text { excerpt presented } \\
\text { to the respondents }\end{array}$} & \multirow{3}{*}{$\begin{array}{l}\text { Correspondingdi } \\
\text { al ogue excerpt } \\
\text { presented to the } \\
\text { respondents in } \\
\text { writing }\end{array}$} & \multirow{3}{*}{$\begin{array}{l}\text { Degree of omitted } \\
\text { word salience }\end{array}$} & \multicolumn{2}{|c|}{$\%$ of respondents, } & \multirow{3}{*}{$\begin{array}{l}\text { No of } \\
\text { differences }\end{array}$} \\
\hline & & & \multicolumn{2}{|c|}{$\begin{array}{l}\text { who identified the difference } \\
\text { correctly }\end{array}$} & \\
\hline & & & $\begin{array}{l}\text { responden ts } \\
\text { with high } \\
\text { level } \\
\text { of anxiety }\end{array}$ & $\begin{array}{l}\text { responden ts } \\
\text { with low } \backslash \text { mode } \\
\text { rate level } \\
\text { of anxiety }\end{array}$ & \\
\hline 1. are you going to & Are you going to & $\underline{\text { on }}-$ non-salient & 55 & 25 & 10 \\
\hline $\begin{array}{l}\text { watch the movie } \\
\text { on TV tonight } \|\end{array}$ & $\begin{array}{l}\text { watch the movie } \\
\text { tonight? }\end{array}$ & $\underline{\mathrm{TV}}$-salient & 66 & 38 & \\
\hline $\begin{array}{l}\text { 3. how did your } \\
\text { parents like the } \\
\text { play they }\end{array}$ & $\begin{array}{l}\text { Did your parents } \\
\text { like the play they } \\
\text { saw last month? }\end{array}$ & how - salient & 89 & 25 & 7 \\
\hline last week\| & & & & & \\
\hline
\end{tabular}

The analysis of the dynamics of text perception allowed making the following conclusions (see Figure 1 as an example):

- students with higher level of trait anxiety are characterized by more detailed perception, the ability to concentrate attention on several areas of activity, despite the worst attention shift; in 
dynamics, the best results of students with higher level of trait anxiety at the beginning of activity are noted (irrespectively of the unit under consideration: a separate dialogue, a series of dialogues, isolated phrases), in contrast with students with low level of general anxiety; the significance of the differences in the curves in the transition area from 1 to 2 dialogues (that is, during the initial stage of activity) is confirmed by testing using criterion $3 \square$, where $\square$ is a selective quadratic deviation of tangents of the slope angles of the curve on the segment; $\square$ with the semantic perception of the sounding English speech students with higher level of general anxiety are characterized by the relatively low speed of the processes of logical comprehension along with fast fatigue; students with low level of general anxiety have despite the stability of the results, relatively slow learning curve, a long period of adaptation to a new type of activity, the worst perception and comprehension of linking elements or transmitting additional elements of text.

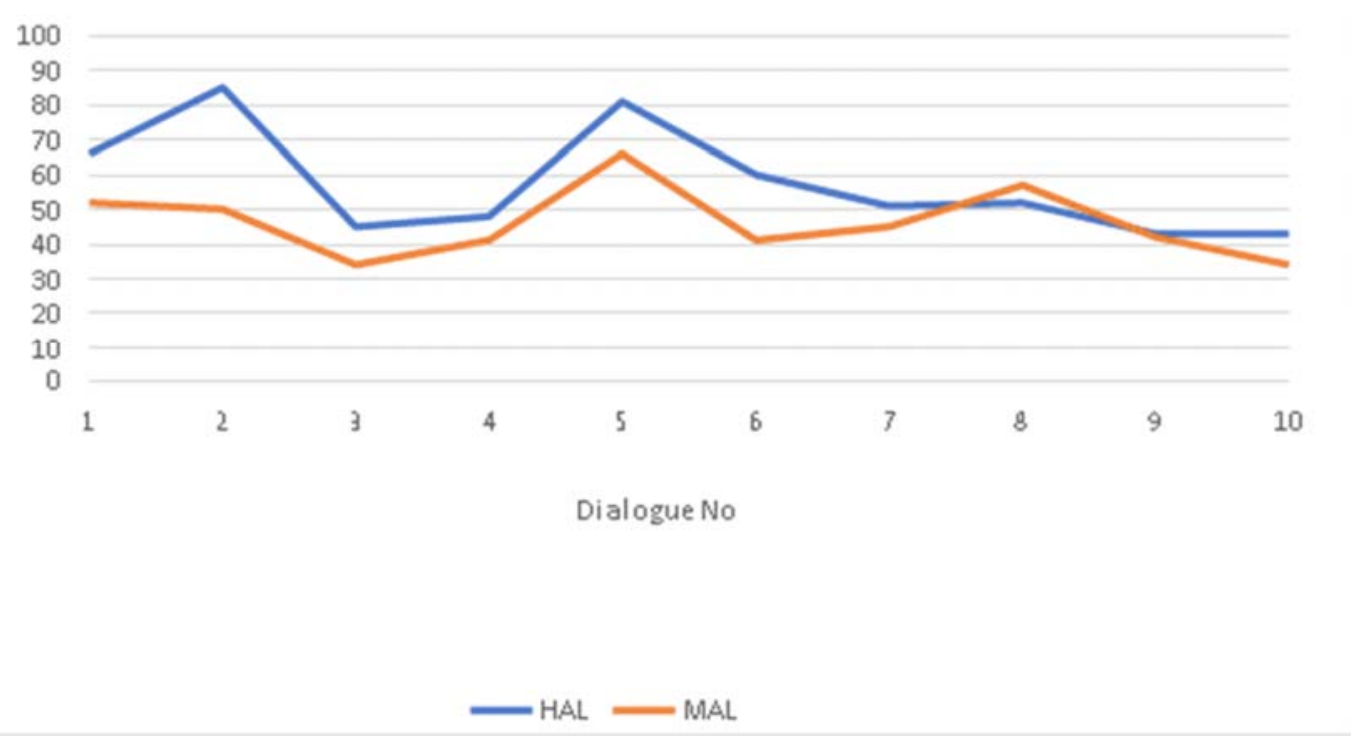

Figure 1. \% of correct answers in the text comprehension experiment by the respondents with different levels of trait anxiety (HAL - high anxiety level, MAL - moderate/low anxiety level)

\section{Discussion}

The experimental results showed that the level of trait anxiety does not have a negative correlation with the successful listening comprehension. On the contrary, the respondents with high level of trait anxiety are characterized by more detailed perception, attention to minor changes, faster adaptation to a new type of activity in contrast with the respondents with low $\backslash$ moderate level of trait anxiety. To mitigate the negative effect of the trait anxiety it is necessary to work at a greater automaticity of language skills and a mechanism of probabilistic forecasting, which leads to a reduction in the attention influence on speech activity and the distancing of fatigue. 
Compensatory role is also played by the development of metacognitive, cognitive, affective and social strategies in terms of O'Mally and Chamot (1990).

So students with higher level of general anxiety should develop metacognitive strategies of selective attention and control; cognitive strategies of deduction and processing.

For students with low level of general anxiety metacognitive strategies of selective attention, planning, control; cognitive strategies of repetition, inference, imaging, transfer, processing are essential.

In terms of developing listening skills they should consciously fulfill the additional tasks compensating the negative influence of the personality traits. The system of these exercises could be classified according to the stage in the learning process: additional types of tasks used throughout the learning process, additional types of tasks used before listening, additional types of tasks performed in the process or immediately after listening to the audio material, features of the organization of the consolidation stage.

The following strategies are to be developed through a system of special tasks:

- for the students with high level of trait anxiety: deduction, self-stimulation, reducing or detracting from the effect of fatigue when listening, stability and selectivity of attention, speed of formation of logical connections.

- for the students with low $\backslash$ moderate level of trait anxiety: selectivity of attention, concentration on those fragments of audio material that contain secondary information or are linking elements, concentrating the attention on the initial fragment of the text and factual information.

This approach applied throughout the year will help:

- all types of students: develop, at a conscious level, the necessary learning strategies;

- students with low level of general anxiety: develop skills of quick adaptation for new types of activity, ability to concentrate on the initial fragment of audio material; reduce the effect of fatigue by automating the skills of highlighting the most informative fragments, correlating them with existing information; adapt to the presence of misunderstood fragments of speech;

- students with higher level of general anxiety: overcome fatigue consciously, concentrate on informatively meaningful elements, develop the abilities of logical comprehension of what has been heard;

- facilitate the work of the teacher as a result of reducing the level of students' fatigue, increasing the effectiveness of their activities.

\section{Conclusion}

The following principles for changing the educational process are to be implemented: taking into account the psychological characteristics of students when testing acquired skills; the division of the study group into subgroups depending on the level of personal anxiety of the students; creating a comfortable environment during classes to reduce the level of situational anxiety of students while maintaining the significance of the results of the tasks performed; using 
the advantages of group and pair work; differentiation of study assignments for selected subgroups; development of compensatory psychological mechanisms during the whole educational process.

Further analysis of the problem in question leads to the conclusion that it is necessary to carry out a set of experiments aimed at identifying factors that determine the course of cognitive processes associated with the processing of verbal information; as well as the development of certain experimental techniques that allow us to identify the relationship between the nature of the semantic perception of foreign-sounding material and the individual characteristics of the communicant.

\section{References}

A Common European Framework of reference for Languages: Learning, teaching, assessment Council of Europe. (2001). Cambridge: Cambridge University Press.

Anderson, A., \& Lynch, T. (1988). Listening. Oxford: Oxford University Press.

Mall-Amiri, B., Nakhaie, N. (2013). Comparing the performance of extrovert and introvert intermediate female efl learners on listening and reading tasks. The International Journal of Language Learning and Applied Linguistics World (IJLLALW), 3 (3), 15-31.

Bradley, J. H., \& Herbert, F. J. (1997). The effect of personality type on team performance. Journal of Management Development, 16, 337-353.

Brown, H.D. (1994). Principles of language learning and teaching (3rd .ed.). Englewood Cliffs, NJ: Princeton Hall.

Cassady, J., \& Johnson, R. (2002). Cognitive test anxiety and academic performance. Contemporary Educational Psychology, 27, 270-295.

Chapelle, C., Roberts, C. (1986). Ambiguity tolerance and field independence as predictors of proficiency in English as a second language. Language Learning, 36: 27-45.

Curry, L. (1983). An organization of learning styles theory and constructs. In Curry L (Ed.) Learning style in continuing education (p 115-131). Halifax: Dalhousie University.

Daneshvari, R. (1996). Extroversion/Introversion and listening comprehension. Unpublished Master's Thesis, Iran: Tehran University.

Ehrman, M., \& Oxford, R. (1995). Cognition plus: Correlates of language proficiency. Modern Language Journal, 79, 67-89.

Gellman, M.D., Turner, J.R. (2013). Encyclopedia of Behavioral Medicine. New York: Springer.

Ewald, J.D. (2007). Foreign language learning anxiety in upper-level classes: Involving students as researchers. Foreign Language Annals, 40, 122-142.

Feist, J., \& Feist, G. J. (2009). Theories of Personality. New York: McGraw-Hill.

Hjelle, L.A. \& Ziegler, D.J. (1992) Personality theories: Basic assumptions, research, and applications (3rd ed.), New York: McGraw-Hill Book Company.

Khanin YU.L. (1976). Kratkoye rukovodstvo $k$ primeneniyu shkaly reaktivnoy $i$ lichnostnoy trevozhnosti CH.D.Spilbergera. Leningrad: LNIITEK. 
Koch A.S., Terrell T.D. (1991). Affective reactions of foreign language students to Natural Approach activities and teaching techniques. In: E. K. Horwitz \& D. J. Young (Eds.), Language anxiety: From theory and research to classroom implications (pp.109-126). Englewood Cliffs, NJ: Prentice-Hall.

Kolb, A. Y. \& Kolb, D. A. (2005). The Kolb Learning Style Inventory - Version 3.12005 Technical Specifications. Boston, MA: Haygroup. Experience Based LearningSystems Inc.

Littlewood, W. (2000). Task-based learning of grammar, In: Hk English Advisory Inspectorate (Eds.): Teaching and Learning Update, 1, 40-57.

Liu, M. (2006). Anxiety in Chinese EFL at different proficiency levels. System 34:301-316. Long, M. H. (1985). A role for instruction in second language acquisition: task-based language teaching. In K. Hyltenstam \& M. Pienemann (Eds.), Modelling and assessing second language acquisition (pp. 77-99). Clevedon, Avon: Multilingual Matters.

MacIntyre, P.D., Gardner, R.C. (1994). The subtle effects of language anxiety on cognitive processing in the second language. Language Learning, 44(2):283-305.

MacIntyre P.D. (1999). Language anxiety: A review of the literature for language teachers. In Young, D.J. (Ed.) Affect in foreign language and second language learning: A practical guide to creating a low anxiety classroom atmosphere.( pp. 24-45). Boston: McGraw-Hill.

MacIntyre P.D., Gardner R.C. (1991). Language anxiety: Its relationship to other anxieties and to processing in native and second languages. Language Learning, 41:513-534.

Markham, S. (2004). Learning Styles measurement:a cause for concern. Technical Report, Computing Educational Research Group.

Nasrabadi, R.D. (1996). Extroversion/introversion \& EFL listening comprehension. Unpublished master's thesis, Iran:. University of Tehran,.

Norakidze, V.G. (1989). Metody issledovaniya kharaktera lichnosti. Tbilisi: Metsniyereba. O'Mally, J.M., Chamot, A.U. (1990). Learning Strategies in Second Language Acquisition. Cambridge: Cambridge University Press.

Prabhu, N. S. (1987). Second Language Pedagogy. Oxford: Oxford University Press.

Saito Y, Samimy K.K. (1996). Foreign language anxiety and language performance: A study of learner anxiety in beginning, intermediate, and advanced level college students of Japanese. Foreign Language Annals, 29: 239251.

Serraj, S. Listening Anxiety in Iranian EFL learners. International Journal of Scientific and Research Publications, $5(6): 1-8$.

Ehrman, M. (1993). Ego boundaries revisited: Toward a model of personality and learning. In J. Alatis (Ed.), Strategic interaction and language acquisition: theory, practice, and research (pp.331-362). Washington, DC: Georgetown University Press.

Tucker, G. R., Hamayan, E., \& Genesee, F. (1976). Affective, cognitive, and social factors in second-language acquisition. Canadian Modern Language Review, 32: 214-226. 